\title{
Investigation of the Relationship between Social Connectedness Level and Just World Beliefs of Prospective Teachers
}

\author{
Yakup Akyel $^{1}$ \\ Ersan Tolukan ${ }^{2}$ \\ 'Department of Basic Education, Faculty of Education, Ahi Evran University, Kirsehir, Turkey \\ Email:yakyel@ahievran.edu.trTel:905053192818 \\ ${ }^{2}$ Department of Sports Sciences, Faculty of Health Sciences, Tildirim Beyazit University, Ankara, Turkey \\ Email:etolukan@ybu.edu.trTel:+905352593140
}

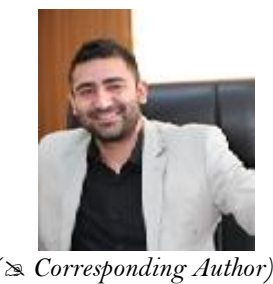

Abstract

This study aims to determine the relationship between social connectedness level and just world belief of prospective teachers in terms of various variables. This study adopted a correlational survey model. 318 volunteer prospective teachers from Department of Visual Arts and Music Education at Faculty of Fine Arts, and Department of Physical Education at Faculty of Education of Ankara and Gazi Universities participated in this study. The General Just World Belief Scale developed by Dalbert (1999) and adapted to Turkish by Göregenli (2003) and the Social Connectedness Scale developed by Lee and Robbins and adapted to Turkish by Duru (2007) were used as a data collection tool. As a result of the research, it was determined that the general just world beliefs of the prospective teachers were at a moderate level and their social connectedness was low. In addition, the general just world beliefs and social connectedness levels of the participants in the $1^{\text {st }}$ and $2^{\text {nd }}$ grades were significantly higher than those in the $3^{\text {rd }}$ and $4^{\text {th }}$ grades. There was no significant relationship between general just world beliefs and social connectedness levels of prospective teachers.

Keywords: Social connectedness, Just world beliefs, University students, Prospective Teacher, Education, Sports Sciences. JEL Classification: I29.

Citation | Yakup Akyel; Ersan Tolukan (2019). Investigation of the Relationship between Social Connectedness Level and Just World Beliefs of Prospective Teachers. Asian Journal of Education and Training, 5(1): 243-247.

History:

Received: 20 December 2018

Revised: 23 January 2019

Accepted: 19 February 2019

Published: 12 March 2019

Licensed: This work is licensed under a Creative Commons

Attribution 3.0 License $(\mathrm{cc}) \mathbf{E}$

Publisher: Asian Online Journal Publishing Group
Contribution/Acknowledgement: Both authors contributed to the conception and design of the study.

Funding: This study received no specific financial support.

Competing Interests: The authors declare that they have no conflict of interests.

Transparency: The authors confirm that the manuscript is an honest, accurate, and transparent account of the study was reported; that no vital features of the study have been omitted; and that any discrepancies from the study as planned have been explained.

Ethical: This study follows all ethical practices during writing.

\section{Contents}

1. Introduction

2. Method

244

3. Results 


\section{Introduction}

It is important to determine the individuals' perceptions related to the general sense of equity belonging to the world as they will participate in active life as a young workforce in the future. The way that the individuals, who will take place in the production phase, perceive the world just can lead to determine where they locate themselves in the system. At the same time, especially in and after the adolescence period, identifying individuals' immediate circle, friends, institutions, and their devotion to their country may also shed light on activities that can be done before starting to work. As only the people who are improved not only cognitively but also affectively can bring desired benefits to society.

\subsection{Belief in a Just World}

Justice is defined by the Turkish Language Association as "ensuring that all rights granted by the law are used by all" or "giving everyone what their rights are; truth" (Türk Dil Kurumu (TDK), 2018). Every word that can be produced like fair, just, unfair, unjust and so on is very important for the people in society. In fact, these words have a great importance in the processes of perception, evaluation and judgment of situations and conditions which people themselves and the others are in Topuz et al. (2017). Belief in a just world emerged as a result of realizing the tendency of people to legitimize the injustice in the events they observed. It was firstly conceptualized as a consequence of Lerner's experimental studies and stated as "a fundamental illusion" regarding the world is fair (Kilinç and Torun, 2011; Sapancı and Bahtiyar, 2018).

The concept of belief in a just world is the belief of individuals concerning that there is a fair system and an individual deserves what $\mathrm{s}$ /he faces as either positive or negative (Furnham, 2003). According to this theory, people tend to believe that everyone gets what they deserve in life. People want to believe that good things in life find good people, bad things find bad ones (Lerner, 1980). This belief allows people to perceive their physical and social environments as static and regular. In this way, people protect themselves from the tension that is created by an uncertain future by making long-term plans (Kilinç and Torun, 2011). From the perspective of social psychology, if people have a desire for justice, it shapes their beliefs and attitudes about the world. As the issue is related to justice, the theory of just world belief basically made it necessary to work together with many different concepts in the psychology literature and it contributes greatly to the literature in this respect (Topuz et al., 2017).

\subsection{Social Connectedness}

Social Connectedness can be defined as the individual's awareness concerning that he is part of the social world and connected with others. Therefore, individuals with high social connectedness tend to feel closer to other people, see people friendly and participate in social groups (Lee and Robbins, 1995). In other words, according to Moore (2006) social connectedness is defined as the ability to turn the individual's social lives, relational networks, peer relationships and family experiences into meaningful relationships that will allow him to feel belonging to a social environment and to consider himself as a part of social life (Kurtyllmaz, 2011). On the other hand, social connectedness is defined as the integration of the satisfaction that the individual receives from his/her social environment and social networks (Timpone, 1998). Thus, social connectedness may help individuals to adapt to their environment, feel safe in social environments, establish easy interactions, and communication (Satıcı, 2016).

\section{Method}

The model of the research, the universe and sampling, data collection tools and data analysis are included in this section.

\subsection{Research Model}

In this study carried out by correlational survey model, it is aimed to investigate the relationship between general just world beliefs and social connectedness levels of prospective teachers, and to determine whether the social connectedness and just world beliefs show a significant difference based on the demographic characteristics of the students.

\subsection{Universe and Sampling}

The universe of the research is composed of students studying at Faculty of Fine Arts, Visual Arts and Music Education Department, Faculty of Education and Sport Sciences, and Department of Physical Education at Ankara University and Gazi University in 2017-2018 education terms. Maximum diversity sampling method was used while selecting samples from the universe. The maximum diversity sampling method is the inclusion of different groups that are homogenous in their relation to the research problem (Büyüköztürk et al., 2014). In this respect, students were included in the study on the basis of volunteerism from each department within the faculty.

The study was carried out with 318 students in total. $27 \%$ of the students $(n=86)$ were in Fine Arts Education, including Art Education and Music Education; 37,7\% $(\mathrm{n}=120)$ of them in Foreign Languages Education Department of Faculty of Education; 35,2\% $(\mathrm{n}=112)$ of them in the Faculty of Sport Sciences. $57.5 \%(\mathrm{n}$ $=183)$ of the students were female and $42.5 \%(\mathrm{n}=135)$ were male. $7.5 \%(\mathrm{n}=24)$ of the students were in the first year, $34.9 \%(\mathrm{n}=111)$ were in the second year, $10.1 \%(\mathrm{n}=32)$ in the third grade, and $47.5 \%(\mathrm{n}=151)$ of them were in the fourth grade. $15,4 \%(\mathrm{n}=49)$ of the students were $17-19$ years old, $69,8 \%(\mathrm{n}=222)$ were $20-22$ years old and $14,8 \%(\mathrm{n}=47)$ were over 22 years of age.

\subsection{Data Collection Tools}

The data of the study were collected through Personal Information Form, General Just World Scale and Social Connectedness Scale. General Just World Belief Scale developed by Dalbert (1999) consists of 6 items. All items in the scale show a positive expression and the items are rated in 5-point Likert type. The lowest score for each item is 1 and the highest score is 5 . The total lowest score is 6 and the total highest score is 30. Low scores from the scale show that the general just world belief is low and the high scores show that the general just world belief is 
high. Dalbert (1999) found Cronbach's alpha reliability coefficient to be 0,78 , which was calculated to determine the reliability of the responses to the scale items. In the study of adaptation of the scale to Turkish, Göregenli (2003) found the reliability of the responses to the scale items as 0.69. The Social Connectedness Scale was developed by Lee and Robbins (1995). The scale consisting of eight items is used to determine the subjective perception of how close people feel themselves to other people. The higher the scores from the scale, the higher the sense of belonging is. There are 8 items that are rated in the 5-point Likert-type scale. The lowest score from each item is 1 ; the highest score is 5 . The total lowest score to be obtained from the overall scale is 8 ; the total highest one is 40 . The low scores on the scale indicate that students have low social connectedness while high scores show high social connectedness. In the development process of the scale, the cronbach alpha coefficient of the Social Connectedness Scale was 0.91; test-retest reliability coefficient was calculated as 0.96. The Turkish adaptation of the scale was made by Duru (2007) and its internal consistency was found as $\alpha=.90$ and test-retest reliability was 0.90. In the adaptation study of Ergün-Başak and Can (2018) it was observed that 8-item and one-dimensional model related to Social Connectedness Scale provided a good fit $(\chi 2 / \mathrm{sd}=5,00, \mathrm{RMSEA}=0,090, \mathrm{SRMR}=0,031$; GFI $=0,95$, AGFI= $0,91, \mathrm{CFI}=0,99, \mathrm{NNFI}=0,98)$. The internal consistency coefficient of the Social Connectedness Scale was found as 0.92 by Ergün-Başak and Can (2018).

\subsection{Data Analysis}

In the analysis of the data, descriptive statistics were firstly calculated, and then homogeneity of the data distribution variance was examined. Independent $t$ test and One Way ANOVA were calculated in the comparisons. The relationship between the scales was examined by Pearson Correlation analysis.

\section{Results}

Table-1. Descriptive statistics of the scores obtained by university students from general just world belief and social connectedness scale.

\begin{tabular}{l|c|c|c|c|c|c}
\hline Scale & Item & N & Lowest & Highest & $\overline{\mathbf{X}}$ & SS \\
\hline General Just World Belief & 6 & 318 & 8,00 & 28,00 & 18,45 & 3,92 \\
\hline Social Connectedness & 8 & 318 & 8,00 & 40,00 & 18,36 & 6,85 \\
\hline
\end{tabular}

Social Connectedness p<0,05*.

As a result of the study, it was found out that the general just world belief scores of university students ranged between 8,00 and 28,00, and the average was calculated as 18,45 ( $\pm 3,92)$. On the other hand, the scores of the students on the social connectedness scale vary between 8,00 and 40,00 . It was found that the average was calculated as $18,35( \pm 6,85)$. In this direction, it is seen that general just world beliefs of students are slightly above average level and their social connectedness level is low.

Table-2. Results of one-way analysis of variance calculated based on the students' departments

\begin{tabular}{|c|c|c|c|c|c|c|}
\hline Scales & Department & $\mathbf{N}$ & $\overline{\mathbf{x}}$ & SD & $\mathbf{F}$ & p \\
\hline \multirow{3}{*}{ General Just World Belief } & Fine Arts Education & 86 & 17,78 & 3,70 & \multirow{3}{*}{5,246} & \multirow{3}{*}{$0,006^{*}$} \\
\hline & Education Sciences & 120 & 18,06 & 4,08 & & \\
\hline & Sports Sciences & 11.2 & 19,39 & 3,75 & & \\
\hline \multirow{3}{*}{ Social Connectedness } & Fine Arts Education & 86 & 19,03 & 7,25 & \multirow{3}{*}{1,252} & \multirow{3}{*}{0,284} \\
\hline & Education Sciences & 120 & 17,60 & 6,96 & & \\
\hline & Sports Sciences & 112 & 18,64 & 6,39 & & \\
\hline
\end{tabular}

It was found that the social connectedness levels of the students participating in the study did not show a significant difference with reference to the departments they study $(\mathrm{F}(2,317)=1,252 ; \mathrm{p}>0,05)$. Nevertheless, their general just world belief showed a significant difference regarding their departments $\left(\mathrm{F}_{(2,317)}=5,246 ; \mathrm{p}<0,05\right)$. After the calculated Tukey post hoc test, it was determined that the general just world beliefs of the students studying in the departments of the Faculty of Sport Sciences were significantly higher than the general just world beliefs of the students studying in the departments of Fine Arts Education and Educational Sciences.

Table-3. T test results in unrelated measurements with regard to the gender of the students.

\begin{tabular}{l|c|c|c|c|c|c}
\hline Scale & Gender & $\mathbf{N}$ & $\overline{\mathbf{X}}$ & $\mathbf{S D}$ & $\mathbf{t}$ & $\mathbf{p}$ \\
\hline \multirow{2}{*}{ General Just World Belief } & Female & 183 & 18,27 & 3,76 & \multirow{2}{*}{0,952} & \multirow{2}{*}{0,342} \\
\cline { 2 - 6 } & Male & 135 & 18,70 & 4,13 & \\
\hline \multirow{2}{*}{ Social Connectedness } & Female & 183 & 17,86 & 6,77 & \\
\cline { 2 - 5 } & Male & 135 & 19,02 & 6,94 & 1,493 & 0,136 \\
\hline
\end{tabular}
$\mathrm{p}<0,05^{*}$.

Regarding the gender of the students, it was revealed that both general just world beliefs $(\mathrm{t}(316)=0,952 ; \mathrm{p}>$ $0,05)$ and social connectedness $(\mathrm{t}(316)=1,493 ; \mathrm{p}>0,05)$ did not show a significant difference.

Table-4. Results of one-way analysis of variance calculated based on the grades (year) of the students.

\begin{tabular}{|c|c|c|c|c|c|c|}
\hline Scales & Grade Level & $\mathbf{N}$ & $\overline{\mathbf{x}}$ & SD & $\mathbf{F}$ & p \\
\hline \multirow{4}{*}{ General Just World Belief } & 1 & 24 & 19,00 & 3,69 & \multirow{4}{*}{4,021} & \multirow{4}{*}{$0,008 *$} \\
\hline & 2 & 111 & 19,28 & 3,86 & & \\
\hline & 3 & 32 & 16,91 & 3,76 & & \\
\hline & 4 & 151 & 18,09 & 3,91 & & \\
\hline \multirow{4}{*}{ Social Connectedness } & 1 & 24 & 20,46 & 7,85 & \multirow{4}{*}{3,554} & \multirow{4}{*}{$0,015^{*}$} \\
\hline & 2 & 111 & 19,59 & 6,62 & & \\
\hline & 3 & 32 & 16,63 & 6,79 & & \\
\hline & 4 & 151 & 17,48 & 6,70 & & \\
\hline
\end{tabular}


General just world beliefs $(\mathrm{F}(3,317)=4,021 ; \mathrm{p}<0,05)$ and social connectedness levels $(\mathrm{F}(3,317)=3,554 ; \mathrm{p}$ $<0,05)$ of the students differed significantly regarding the grade they are in. As a result of the calculated Tukey post hoc test; it was found that general just world beliefs of the third graders were lower than those of first and second grade students. Similarly, it was found that the social connectedness levels of the students in the third and fourth year were lower than those of the first and second year students.

Table-5. The relationship between general just world beliefs and social connectedness levels of students

\begin{tabular}{l|c|c}
\hline Scale & Values & Social Connectedness \\
\hline \multirow{2}{*}{ General Just World Belief } & $\mathrm{r}$ & $-0,061$ \\
\cline { 2 - 3 } & $\mathrm{p}$ & 0,278 \\
\cline { 2 - 3 } & $\mathrm{n}$ & 318 \\
\hline
\end{tabular}

There was no significant relationship between general just world beliefs and social connectedness levels of university students $(n=318 ; r=-0,061 ; p>0.05)$. The relations were also examined on the basis of department, and similarly it was observed that general just world belief level and social connectedness level of the students at Fine Arts Education $(n=86 ; r=0,053 ; p>0,05)$, Educational Sciences $(n=120 ; r=-0,135 ; p>0,05)$ and Faculty of Sport Sciences $(n=112 ; r=-0,078 ; p>0.05)$ showed no significant change.

\section{Discussion and Conclusion}

It was determined that the general just world beliefs of the prospective teachers who participated in the research were at a moderate level.

According to Otto and Dalbert (2005) individuals with a high just world belief are more hopeful and positive about the future, more confident in achieving their goals. However, the bad events experienced over time in achieving their goals undermine these basic assumptions regarding the just world (Gökler and Berberoğlu, 2016). When the research result is evaluated in this respect, that the sample group is composed of university students may have played a role in having a moderate just world belief. As the belief in a just world can be explained by the experience and the difficulties encountered in life, the increase in unfair experiences witnessed by the individuals can cause to decrease their beliefs in a just world (Giray, 2009). In fact, the belief in a just world may not directly reflect the current situation in society. Lerner (1980) states that the world is not a fair place in reality and the belief in a just world is a fundamental illusion by expressing that people want to believe it instinctively as so.

The fact that just world beliefs of the participants were intermediate in general in the studies that were carried out with different participants group in Turkey is parallel with the results of the current study (Giray, 2009; Yıldırım and Akgün, 2013; Kurt and Keser, 2017).

As a result of the study, it was found that the social connectedness of the participants was low Table 1. This result is quite thought-provoking, especially when it is considered together with the fact that the sense of social connectedness in adolescence and early adulthood has an important place in the individual's life.

In fact, experiences related to the development of social connectedness during childhood, adolescence and early youth provide the development of self-sense in individuals. Thus, when individuals with high levels of social connectedness are excluded from the group or experience a loss, their levels of social connectedness do not decrease significantly (Lee et al., 2002).

Social connectedness, however, is a psychosocial structure that is influenced by various factors and that affects various factors. Negative interpersonal relationships, unsafe attachment status, traumatic experiences, negative parent, teacher and peer attitudes, rejection, exclusion and distrust adversely affect the development of social connectedness. In the relevant literature, internet addiction is considered to be the most important factor preventing the development of social connectedness (Savc1, 2017). Therefore, many factors may have played a role in that the results occur in this way.

While the social connectedness levels of prospective teachers participating in the study did not show a significant difference on the basis of their departments, the general just world beliefs of those studying in the department of physical education were significantly higher than the participants in the other departments Table 2.

According to these results, with relation to the population of the study, it can be said that prospective physical education teachers have a higher belief in legitimizing positive or negative situations compared to the other departments and they are safer and more positive about the future.

In terms of gender variables, it was found that general just world beliefs and social connectedness levels of prospective teachers were similar Table 3. In other words, gender had no effect in this study. Although it is supposed that women, who frequently face injustices in society, have a lower belief of just world than men do, the results of this study are parallel with the studies which revealed that general just world belief (O'Connor et al., 1996; Berry et al., 2001; Cevikbaş, 2018) and social connectedness (Atak, 2018) did not differ in terms of gender.

It was determined that both general just world beliefs and social connectedness levels of prospective teachers showed a significant difference with regard to the grades in which they study Table 4. As grade level of the participants increased, their just world beliefs and social connectedness decreased significantly.

University education can be considered as an important beginning of professional life. Therefore, the fact that prospective teachers' social anxieties and fair world beliefs decreased significantly in the third and fourth grades indicates that prospective teachers, who will raise future generations, cannot manage their needs and emotions effectively. They are also at risk of having low self-respect, being more prone to be anxious and depressed (Traş and Güngör, 2011; Cetinkaya, 2018) and being more hopeless about the future (Gökler and Berberoğlu, 2016).

According to the correlation results of the data obtained from the research, it was determined that there was no significant relationship between general just world beliefs and social connectedness levels of prospective teachers. In other words, it was determined that two variables did not affect each other Table 5.

This is a result contradicting with the paradigms -at the beginning of the study- that there is a relationship between general just world beliefs and social connectedness. The idea that the increase of just world belief of an 
individual may affect the legitimacy of positive or negative situations in the social life and the increase of the social connectedness differs with the results of the research. According to Struble (2010) individuals with high sense of social connectedness believe that the social system operates in a hierarchy to protect the rights of all. According to these individuals, the legal and traditional structure in society constitutes a guarantee for every individual in need (Ergün-Başak and Can, 2018). In their research, Oldmeadow and Fiske (2007) stated that individuals with just world beliefs see social inequalities as more just and legitimate. Heaven et al. (2000) found that social dominance tendencies were high for groups with high world beliefs. The low social connectedness levels of the sample group may have played a role in that the correlation results between two variables occurred differently from expected.

\section{References}

Atak, B., 2018. Examining the relationship between social commitment and social anxiety levels of universty students. Master's Thesis (Unpublished), Gazi University, Institute of Health Sciences, Ankara.

Berry, J., E. Worthington, L. Parrott, L. O'Connor and N. Wade, 2001. Dispositional forgiveness: Development and construct validity of the transgression narrative test of forgiveness (TNTF). Personality and Social Psychology Bulletin, 27(10): 1277-1290.Available at: https://doi.org/10.1177/01461672012710004.

Büyüköztürk, Ş., E.K. Çakmak, Ö.E. Akgün, Ş. Karadeniz and F. Demirel, 2014. Scientific research method. Ankara: Pegem Academy.

Cetinkaya, T., 2018. Academic research in sports sciences. Ankara: Gece Library.

Cevikbaş, P.E., 2018. Developmental investigation of elementary and high school students' beliefs in a just world in terms of locus of control and parental attitudes. Doctoral Dissertation, Hacettepe University, Institute of Health Sciences, Ankara.

Dalbert, C., 1999. The world is more just for me than generally: About the personal belief in a just world scale's validity. Social Justice Research, 12(2): 79-98.

Duru, E., 2007. An adaptation study of social connectedness scale in Turkish culture. Eurasian Journal of Educational Research, 7(26): 85-94.

Ergün-Başak, B. and G. Can, 2018. The relationships between self-compassion, social-connectedness, optimism and psychological resilience among low-income university students. Elementary Education Online, 17(2): 768-785.

Furnham, A., 2003. Belief in a just world: Research progress over the past decade. Personality and Individual Differences, 34(5): 795817.Available at: https://doi.org/10.1016/s0191-8869(02)00072-7.

Giray, F.S., 2009. Analysing the relation between the forgiveness and just world belief of perpetrator and non-perpetrator adolescents. Master's Thesis, Maltepe University, Institute of Social Sciences, İstanbul.

Gökler, D.I. and E. Berberoğlu, 2016. Analysis of the relationship between the childhood experiences of abuse and just world belief İn delinquent adolescents. Anatolian Journal of Psychiatry, 17(2): 111-119.Available at: https://doi.org/10.5455/apd.177638.

Göregenli, M., 2003. Assessments and experiences of violence, Illl-treatment and torture. The Role of Lawyers in the Prevention of Torture Report, İzmir Bar Association Publications.

Heaven, P., R. Greene, C. Stones and P. Caputi, 2000. Levels of social dominance orientation in three societies. The Journal of Social Psychology, 140(4): 530-532.Available at: https://doi.org/10.1080/00224540009600491.

Kilinç, S. and F. Torun, 2011. Belief in a just world. Current Approaches in Psychiatry, 3(1): 1-14.

Kurt, M. and H. Keser, 2017. Investigation of digital citizenship levels of preservice teachers according to individual and general just world belief. 11. International Computer and Instructional Technology Symposium, 24-26 May., Malatya. Abstract Book. pp: 771-773.

Kurtyılmaz, Y., 2011. Relationships among relational aggression and self esteem, social connectedness and social anxiety levels of university students. Doctoral Dissertation, Anadolu University Institute of Educational Sciences, Eskişehir.

Lee, R., K. Keough and J. Sexton, 2002. Social connectedness, social appraisal, and perceived stress in college women and men. Journal of Counseling \& Development, 80(3): 355-361.Available at: https://doi.org/10.1002/j.1556-6678.2002.tbo0200.x.

Lee, R. and S. Robbins, 1995. Measuring belongingness: The social connectedness and the social assurance scales. Journal of Counseling Psychology, 42(2): 232-241.Available at: https://doi.org/10.1037//0022-0167.42.2.232.

Lerner, M.J., 1980. The belief in a just world. In the belief in a just world. Boston, MA: Springer. pp: 9-30.

Moore, T.L., 2006. Social connectedness and social support of doctoral students in counselor education. Doctoral Dissertation, Idaho State University, Idaho, USA.

O'Connor, W.E., T. Morrison, L. McLeod and D. Anderson, 1996. A meta-analytic review of the relationship between gender and belief in a just world. Journal of Social Behavior and Personality, 11(1): 141-148.

Oldmeadow, J. and S. Fiske, 2007. System-justifying ideologies moderate status= competence stereotypes: Roles for belief in a just world and social dominance orientation. European Journal of Social Psychology, 37(6): 1135-1148.Available at: https://doi.org/10.1002/ejsp.428.

Otto, K. and C. Dalbert, 2005. Belief in a just world and its functions for young prisoners. Journal of Research in Personality, 39(6): 559573.Available at: https://doi.org/10.1016/j.jrp.2005.01.004.

Sapanc1, A. and M. Bahtiyar, 2018. The predictive power of just in world belief, hope, positive and negative affect, perceived social support for meaning in life. Electronic Turkish Studies, 13(19): 1537-1549.

Satıcı, S.A., 2016. Forgiveness, vengeance, social connectedness and subjective well-being of university students: A study on examining different structural models. Doctoral Dissertation, Anadolu University Institute of Educational Sciences, Eskişehir.

Savcı, M., 2017. Relationships among relational social connectedness, internet addiction, peer relations, social anxiety and social intelligence levels of adolescents. Doctoral Dissertation, Dokuz Eylül University Institute of Educational Sciences. İzmir.

Struble, S.S., 2010. Role of social connectedness in weight related health behaviors: Implications for community health promotion programme. Doctoral Dissertation. Texas Woman's University, Texas.

Timpone, R., 1998. Ties that bind: Measurement, demographics, and social connectedness. Political Behavior, 20(1): 53-77.

Topuz, A.G., O. Uca and M. Topuz, 2017. A polemos on just world belıef. International Journal of Social Inquiry, 10(2): 257-275.

Traş, Z. and H.C. Güngör, 2011. A qualitative study on social support and social connectedness issues in regard to university students of Turkish origin coming from European countries. Selçuk University The Journal of Institute of Social Sciences, 25(1): $261-271$.

Türk Dil Kurumu (TDK), 2018. Current Turkish dictionary, justice. Available from http://www.tdk.gov.tr/index.php?option=com_gts\&arama=gts\&guid=TDK.GTS.5c76788408ff14.92231619 14.08.2018].

Yıldırım, N. and S. Akgün, 2013. Perceived legitimacy of the social system, belief in a just world and social dominance orientation of volunteers in non-governmental organizations. Journal of Society and Social Work, 24(1): 115-128. 